\title{
REVIEW
}

\section{DARFUR PEACEREEPERS}

In 2021, the French publishing house L'Harmattan published a monograph entitled Darfur peacekeepers the African Union peacekeeping mission in Darfur (AMIS) from the perspective of a Hungarian military advisor.

The author of the 234-page monograph is Janos Besenyo. In addition to the author's preface and the conclusion, the monograph includes six substantive chapters. In the first chapter entitled Geography and history of Darfur, the author presents the geography, climate, flora and fauna, major cities, economy, infrastructure, different nationalities, ethnic groups and religions, and the history of Darfur.

In the second chapter, entitled AMIS, he focuses on the African Union's mission in Sudan I (AMIS I), presenting the causes of the Darfur conflict, its outbreak and the African Union's engagement in the conflict with the African Union's mission in Sudan.

This is followed by a chapter entitled AMIS II, which presents the history, structure and operation following the decision to engage additional civilian and military observers, soldiers, police officers and additional financial and other resources.

The fourth chapter presents a new mission called AMIS II E or AMIS III, which is also the title of the chapter. The letter E in the acronym stands for the word "enhanced," which implied the enhanced character of military presence in this mission. This chapter is composed of a subchapter entitled The Foreshadow of the Fall and the additional engagement of the United Nations, followed by the UN and African Union mission in Darfur, known as UNAMID. 
In the fifth chapter, entitled The Support Mission of the European Union, and its four substantive subchapters, the author presents several phases of the European Union's participation in the mission led by the African Union. Chapter six, entitled Hungarian Experience, describes Hungarian experiences from the missions in Darfur. Hungary first deployed its military observer to Darfur in 2004.

Hungary's involvement in the mission in Africa seems unusual, as it was the only one of all the participating countries that had no colonial history, economic or any other interests in this part of the world, and at the same time had no previous experiences. The monograph has only one drawback, and that is the fact that it is not scientific. However, this is at the same time its advantage.

Besenyo was an officer in the Hungarian Armed Forces for 31 years and was deployed in Darfur in the second half of 2005. He was strongly marked by his personal experience as a peacekeeper. Ever since, he has been devoting much attention to Africa-related security topics. His return from the mission of the African Union, the European Union, NATO, the United Nations and other organisations in Darfur coincided with his doctoral studies. Both of these activities have achieved the same effect as two rivers, which merge at the confluence and gain a lot of power and speed as their flow continues.

After completing his military career, the author of the monograph, who is a prolific writer and restless researcher, became actively involved in the academic environment as a university professor at the Obuda University in Budapest. In 2019, the Africa Research Institute was established within the Doctoral School of Safety and Security Sciences, University of Óbuda, headed by Assistant Professor Besenyo, $\mathrm{PhD}$. Considering the amount and quality of publications concerning the African continent, the institute is clearly very successful.

From a European point of view, Africa is a very distant continent; however, the developments in that region and their results are increasingly affecting all of us in the European Union and beyond. The migration flow, which brought many African migrants to the shores of the Mediterranean over the last decade and peaked in 2015, has significantly changed and affected all the countries along their way, especially those that migrants had chosen as their target countries.

Since everyone should have the right to live at home in peace, in their own way, with their family, it would be right that they are enabled to do so. Unfortunately, climate change, water scarcity, disease, poverty, differences in culture, religion, political order and natural resources, but sometimes only individuals or smaller associations, lead to various frictions, conflicts or even genocide, as was the case in Darfur. In such cases, the international humanitarian community and various security and other organizations are usually involved to assist the helpless population. In his monograph, Besenyo presented the full breadth and magnitude of international humanitarian 
efforts, but also the harsh reality where all those who want to help are exactly where they need to be, but despite all their efforts, they are completely powerless.

I recommend Darfur Peacekeepers to be read by all those who care about the future of all of us and our descendants, but especially by those who have the opportunity and ability to influence the security of the country, the society and the individual. The content of the book provides an invaluable insight into the experience of a military officer. It is a valuable learning resource for all of us, but especially for members of the armed forces, police and civilian institutions that lead or support the activities within international missions. 